\title{
Antibodies to neutrophil cytoplasmic antigens in Wegener's granulomatosis and other conditions
}

\author{
D J HARRISON, R SIMPSON, R KHARBANDA, V E ABERNETHY, G NIMMO \\ From the University Departments of Pathology and Rheumatology and the Medical Renal Unit, Royal \\ Infirmary, Edinburgh
}

ABSTRACT The use of serum antibodies to neutrophil cytoplasmic antigens (ANCA) as a diagnostic marker for Wegener's granulomatosis and other forms of vasculitis has been assessed. Although ANCA have been described by several groups the precise antigenic targets are unknown, and detection of ANCA still relies on an indirect immunofluorescence assay technique. Several different patterns of fluorescence have been produced by using sera from different groups of patients, and insufficient information is available on the frequency of positive results and of the patterns of immunofluorescence obtained when serum from patients with vasculitis as a part of a generalised connective tissue disease is used. A study was carried out on serum from 240 patients, including 23 patients with Wegener's granulomatosis, 12 with microscopic polyarteritis, and 30 with various connective tissue diseases. Three patterns of fluorescence were observed: bright coarsely granular cytoplasmic, bright non-granular cytoplasmic, and weak diffuse cytoplasmic. The bright, coarsely granular pattern was $86 \%$ specific for Wegener's granulomatosis in this series and was observed in 18 of 23 cases. Other patterns of fluorescence were found in various conditions and were not of diagnostic value. The technique is simple, inexpensive, rapid, and reproducible.

\section{Introduction}

Wegener's granulomatosis is classically defined as a necrotising granulomatous vasculitis in the upper and lower respiratory tracts associated with focal and segmental necrotising glomerulonephritis. ${ }^{1}$ The classical features are frequently absent, however, and diagnosis is therefore delayed.

The recognition of autoantibodies directed against a neutrophil cytoplasmic antigen (ANCA) in Wegener's granulomatosis $^{23}$ has led to hopes of a specific diagnostic marker for this disease. ANCA may also be useful in monitoring disease activity, ${ }^{23}$ particularly when used with measurement of C-reactive protein. ${ }^{4}$

It is clear that ANCA represent a group of different antibodies as different patterns of fluorescence may be obtained from different serum samples. ${ }^{5}$ The original description described bright, granular fluorescence of the neutrophil cytoplasm in an indirect immuno-

Address for reprint requests: Dr D J Harrison, Department of Pathology, University of Edinburgh, Edinburgh EH9 8AG.

Accepted 3 March 1989 fluorescence assay as diagnostic of Wegener's granulomatosis. ${ }^{2}$ ANCA have, however, been described in microscopic polyarteritis, ${ }^{67}$ Kawasaki disease, ${ }^{8}$ Churg-Strauss syndrome, ${ }^{9}$ and even carcinoma of the lung. ${ }^{10}$ In microscopic polyarteritis, where the pattern of fluorescence has been specified, ${ }^{67}$ a bright, diffuse cytoplasmic fluorescence has been recorded.

This study investigates the pattern of fluorescence produced by ANCA in serum samples from patients with a wide range of diseases, and assesses the clinical value of detecting ANCA by an indirect immunofluorescence assay.

\section{Methods}

IMMUNOFLUORESCENCE ASSAY

The assay used is a modification of that described by Van der Woude and colleagues. ${ }^{2}$ In brief, heparinised venous blood from a healthy volunteer was mixed with half its volume of 5\% Dextran 250 (Pharmacia, UK) in $0.9 \%$ sodium chloride solution, and incubated at $37^{\circ} \mathrm{C}$ for 40 minutes to sediment red blood cells. The neutrophil enriched supernatant was washed twice in 
phosphate buffered saline and resuspended at a cell concentration of $5 \times 10^{5} \mathrm{cells} / \mathrm{ml}$. Aliquots of $100 \mu \mathrm{l}$ were used to make cytospin preparations, which were fixed in absolute ethanol at $4^{\circ} \mathrm{C}$ for five minutes. In some experiments cytospin preparations were fixed in acetone at $4^{\circ} \mathrm{C}$ for five minutes. They were used either immediately or within five weeks, having been wrapped and stored at $-20^{\circ} \mathrm{C}$ until use.

Cytospin preparations were incubated with the patient's serum serially diluted from $1: 20$ or $1: 80$ in phosphate buffered saline for 45 minutes. After two washes in the saline they were incubated with a 1:50 dilution of fluorescein conjugated rabbit antihuman IgG (Scottish Antibody Production Unit, Carluke) for 30 minutes before examination with an ultraviolet microscope. A known positive and a known negative serum sample were included each time the assay was performed.

Cytospin preparations were scored according to the nature and brightness of fluorescence to give four groups: 1-no appreciable fluorescence; 2-weak, diffuse cytoplasmic fluorescence; 3-bright but not coarsely granular cytoplasmic fluorescence; 4 bright, coarsely granular cytoplasmic fluorescence identical to or brighter than the positive control. The presence of antinuclear antibodies was also recorded. The dilution of serum at which fluorescence disappeared was also recorded for positive cases.

\section{CLINICAL DIAGNOSES}

The diagnosis was recorded for each patient studied without prior knowledge of the presence or absence of ANCA. The diagnosis of Wegener's granulomatosis was supported in every case by the histological appearance of biopsy material obtained from at least one affected tissue. Diagnoses were not altered in the light of the ANCA findings.

\section{Results}

\section{CLINICAL}

Twenty three patients with Wegener's granulomatosis were studied. A brief summary of symptoms at presentation and biopsy findings is given in table 1 . Serum samples from a further 217 patients were also studied, including 12 patients with microscopic polyarteritis, three with Churg-Strauss syndrome, 38 with various connective tissue diseases, 41 with renal disease, 10 with malignancy, and the remainder with various inflammatory and infectious disorders (table 2).

\section{IMMUNOFLUORESCENCE}

No normal volunteers had ANCA detectable at serum dilutions of 1:20 or greater. Results of the ANCA test are summarised in table 2. The scoring system for
Table 1 Details of patients with Wegener's granulomatosis

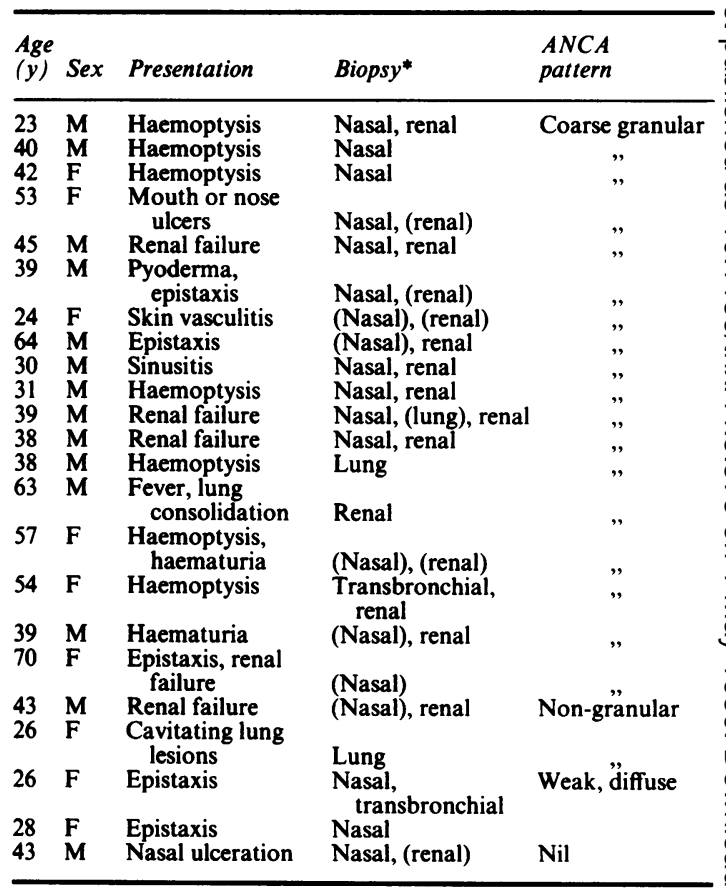

*Parenthesis indicates that although the biopsy was performed it yielded findings that did not support the diagnosis of Wegener's $\vec{F}$ granulomatosis. In other cases biopsy findings were either consistent $\vec{O}$ with or diagnostic of systemic vasculitis.

ANCA-antineutrophil cytoplasmic antibodies.

ethanol fixed cytospin preparations was found to be reliable and reproducible, and two pathologists not $\frac{0}{2}$ concerned with the project concurred with the scores $x$ we had assigned. The scoring was helped by the 윽 inclusion of a known positive sample in each assay. When acetone was used as a fixative the pattern of $O$ fluorescence was usually diffuse and only erratic granular staining was seen. Serum samples from 21 욱 patients, of whom 18 had Wegener's granulomatosis, $\frac{D}{O}$ showed the very bright, coarsely granular cytoplasmic fluorescence characteristic of the positive control $N$ (fig 1).

There were 23 cases of Wegener's granulomatosis in total, giving a sensitivity of $78 \%$ for the test. Of the $\omega$ 217 patients studied who did not have Wegener's? granulomatosis, only three had a positive result. This $\stackrel{0}{\circ}$ gives a specificity of $86 \%$, though this would be $\mathbb{D}$ influenced by the composition of the control group. ? Nineteen patients, of whom two had Wegener's 0 granulomatosis, had bright but non-granular cyto- $\frac{O}{\mathbb{D}}$ plasmic fluorescence (fig 2).

As the fluorescence score decreased the range of $\stackrel{\mathbb{Q}}{\mathscr{Q}}$ diseases with detectable ANCA increased. The 0 inclusion of patterns other than the very bright $O$ 
Table 2 Results of immunofluorescence findings for antineutrophil cytoplasmic antibodies (ANCA) according to the nature of the cytoplasmic fluorescence and the clinical diagnosis

\begin{tabular}{|c|c|c|}
\hline $\begin{array}{l}\text { Cytoplasmic } \\
\text { fluorescence }\end{array}$ & $\begin{array}{l}\text { No of } \\
\text { cases }\end{array}$ & Diagnosis (n) \\
\hline $\begin{array}{l}\text { Bright } \\
\text { coarsely } \\
\text { granular }\end{array}$ & 21 & $\begin{array}{l}\text { Wegener's granulomatosis (18) } \\
\text { Microscopic polyarteritis (2)* } \\
\text { Churg-Strauss syndrome (1)† }\end{array}$ \\
\hline $\begin{array}{l}\text { Bright, non- } \\
\text { granular }\end{array}$ & 19 & $\begin{array}{l}\text { Wegener's granulomatosis (2) } \\
\text { Microscopic polyarteritis (3). } \\
\text { Mixed connective tissue disease (3) } \\
\text { Paget's disease of bone (1) } \\
\text { Churg-Strauss syndrome (1) } \\
\text { Behcet's syndrome (1) } \\
\text { Wegener's granulomatosis (treated) (2) } \\
\text { Nephrosclerosis (2) } \\
\text { Polymyalgia rheumatica }\end{array}$ \\
\hline Weak & 38 & $\begin{array}{l}\text { Wegener's granulomatosis (2) } \\
\text { Microscopic polyarteritis (5) } \\
\text { Mixed connective tissue disease (2) } \\
\text { Rheumatoid arthritis (3) } \\
\text { Churg-Strauss syndrome (1) } \\
\text { Paget's disease of bone (3) } \\
\text { Other diagnoses (22) } \ddagger\end{array}$ \\
\hline Insignificant & 162 & $\begin{array}{l}\text { Wegener's granulomatosis (1) } \\
\text { Microscopic polyarteritis (2) } \\
\text { Other diagnoses, including pneumonia, nasal } \\
\text { polyps, myeloma, Behcet's syndrome, } \\
\text { sarcoidosis, Goodpasture's syndrome, } \\
\text { polymyalgia rheumatica, Wegener's } \\
\text { granulomatosis (treated), polyarteritis } \\
\text { (treated) }\end{array}$ \\
\hline
\end{tabular}

*Focal and segmental necrotising glomerulonephritis.

tEosinophilia, transbronchial biopsy.

IIncluding Wegener's granulomatosis and polyarteritis during treatment, glomerulonephritis, sarcoidosis, systemic lupus erythematosus, Goodpasture's syndrome. granular cytoplasmic fluorescence therefore resulted in reduced specificity of the assay.

ANCA were readily detectable in neutrophil cytospin preparations stored for up to five weeks. This allows the preparation of large batches of fixed slides, which is convenient if the test is to be performed rapidly as a diagnostic aid when required. Repeated freeze-thawing of serum samples resulted in a reduction in ANCA fluorescence, but samples stored for four years at $-70^{\circ} \mathrm{C}$ retained fluorescence.

As serum giving a coarsely granular pattern was diluted we noted that the pattern of fluorescence changed to diffuse before the fluorescence signal actually disappeared. This change occurred at a serum dilution of $1: 80$ in one case, at 1:160 in most cases, and at 1:500 in only two cases. Repeat samples from patients having treatment sometimes showed a similar change in pattern of fluorescence from granular to diffuse, irrespective of the titre of antibody used.

The titre of antibody fell in parallel with other markers of disease activity, such as the white blood cell count, erythrocyte sedimentation rate, and serum concentration of human neutrophil elastase." With recrudescence of clinical disease, such as mouth ulceration, lung cavitation, or deteriorating renal function, the titre of ANCA increased.

\section{Discussion}

The classification of vasculitis is difficult and at times

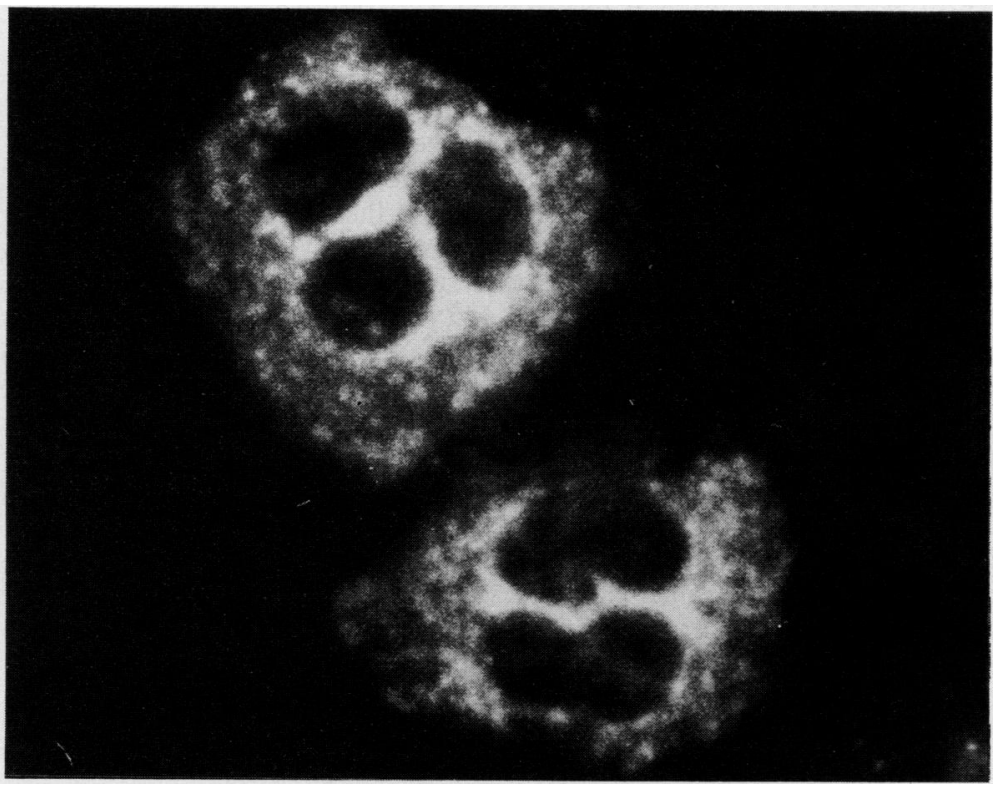

Fig 1 Photomicrograph of cytospin preparation of normal neutrophils incubated sequentially with serum from a patient with Wegener's granulomatosis and fluoresceinated antihuman IgG, showing coarse granular cytoplasmic fluorescence. 


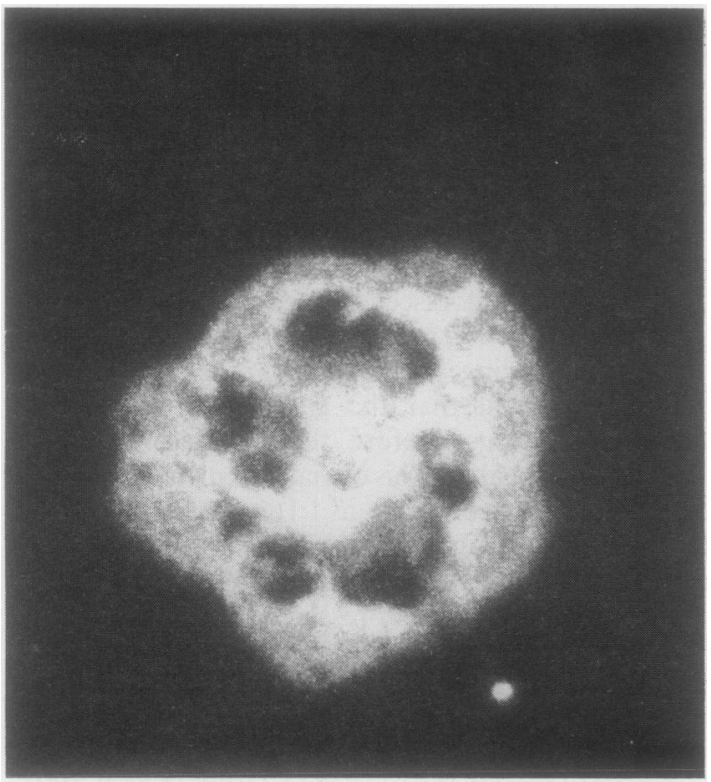

Fig 2 Photomicrograph of a neutrophil cytospin preparation with a more diffuse cytoplasmic fluorescence than in figure 1 after incubation with serum from a patient with microscopic polyarteritis.

unclear. ${ }^{12}$ Primary vasculitis is generally accepted as having an immunological basis, probably with immune complexes damaging the vascular wall. ${ }^{1}$ The diagnosis of Wegener's granulomatosis is frequently delayed because of the difficulty of obtaining definitive diagnostic material. ${ }^{73}$ The discovery of ANCA (a generic rather than a specific title), which are thought to be specific for Wegener's granulomatosis, was therefore hoped to be an important advance in the recognition of this disease and its differentiation from other vasculitides, in particular microscopic polyarteritis. ${ }^{24}$ The reported sensitivity of ANCA tests for active Wegener's granulomatosis has varied from $71 \%$ to $100 \%,{ }^{2410}$ which is similar to the $78 \%$ in our series. We have found ANCA in a few cases of microscopic polyarteritis and Churg-Strauss syndrome but our specificity of $86 \%$ for Wegener's granulomatosis is high, and similar to the range of $88-100 \%$ reported in other series. ${ }^{241014}$ The precise figure for specificity is likely to vary a little as it will be influenced by the composition of the control group. These results are equivalent to accepted values for anti-double stranded DNA antibodies in systemic lupus erythematosus and antiacetylcholine receptor antibodies in myasthenia gravis. ${ }^{4}$

In addition to the very bright, granular cytoplasmic fluorescence that we regard as characteristic of Wegener's granulomatosis many samples had ANCA activity, albeit with less intense and diffuse fluorescence, including serum from four patients with Wegener's granulomatosis, six patients with micro-? scopic polyarteritis, and two patients with Churg- $\frac{-}{\bar{c}}$ Strauss syndrome. Other groups have reported diffuse ${ }_{\odot}$ fluorescence and have included this pattern under the 0 title of ANCA. ${ }^{2}$ It seems likely that more than onew antigen is recognised by $\mathrm{ANCA}^{15}$ and the pattern of $\vec{\circ}$ fluorescence may relate to the antigen or antigensrecognised by the antibodies present in the serum. ${ }^{16} \vec{\omega}$ Many cases of connective tissue diseases as well as? several cases of Paget's disease of bone were included $x$ in our study group. Diffuse, weak ANCA fluorescence $+\stackrel{+}{+}$ has been described in serum from patients withor primary biliary cirrhosis, ${ }^{17}$ rheumatoid arthritis, ${ }^{14} \omega$ bronchogenic carcinoma, ${ }^{10}$ and viral enteritis. ${ }^{10}$ The ${ }^{\omega}$ meaning of these findings is not clear but they suggest $\triangle$ that antibodies to neutrophil cytoplasmic antigens are $\overrightarrow{-}$ a heterogeneous group of antibodies directed against different antigenic determinants and not a single entity. In cases of mixed connective tissue disease theres is a well described antibody to extractable nuclearto antigen. ${ }^{18}$ Our present findings of cytoplasmic fluorescence in this condition may be the result of artefactuals displacement of nuclear antigen during preparation of neutrophils for cytospin, in a way similar to the proposed displacement of nuclear c-myc oncoprotein $\Phi$ during tissue fixation from the nucleus to the cyto- $\Rightarrow$ plasm. ${ }^{19}$ Patients with Wegener's granulomatosis do윽 not usually have other specific autoantibodies. ${ }^{4}$

The weak ANCA fluorescence found in cases of Paget's disease of bone are of interest. Lockwood and colleagues $^{6}$ have proposed that the target antigen of ANCA in vasculitis is an epitope (antigenic determinant of known structure) derived from alkaline phos-ö phatase, though this is controversial. ${ }^{172021}$ If alkaline 3 . phosphatase is an autoantigen, then ANCA may be a epiphenomenon related to increased serum concentra- 3 tions of the enzyme as a result of neutrophil degranula-o tion. In Paget's disease the serum concentration of bone alkaline phosphatase is raised, so possiblyo ANCA are the result of cross reactivity between epitopes of bone and neutrophil alkaline phosphatase. A similar argument may apply to similar antineutro- $N$ phil cytoplasm fluorescence detected in cases of primary biliary cirrhosis. ${ }^{17}$ In these cases the fluores- -0 cence is weak and difiuse, similar to that seen with rabbit anti-human alkaline phosphatase antiserum. ${ }^{20} \frac{\mathrm{C}}{\mathrm{D}}$

In conclusion, the presence of ANCA giving bright $\stackrel{\infty}{\leftrightarrows}$ granular cytoplasmic fluorescence is of considerable value in suggesting the diagnosis of Wegener'so

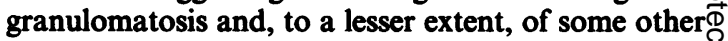
vasculitides. The indirect immunofluorescence assay is $\stackrel{0}{\mathbb{D}}$ rapid, reliable, reproducible, inexpensive, and within the capabilities of most laboratories. Further iden-< tification of the antigenic epitopes concerned mayô 
increase both the specificity and the sensitivity of testing for ANCA in the diagnosis and follow up of Wegener's granulomatosis, and increase our understanding of the underlying disease process.

This work was supported by a grant to DJH from the British Medical Association, and forms part of a thesis submitted by RS to the Institute of Medical Laboratory Sciences, London.

\section{References}

1 Cupps TR, Fauci AS. The vasculitides. Philadelphia: Saunders, 1981:26.

2 Van der Woude FJ, Lobatto S, Permin H, et al. Autoantibodies against neutrophils and monocytes: tool for diagnosis and marker of disease activity in Wegener's granulomatosis. Lancet 1985;i:425-9.

3 Gross WL, Ludemann G, Kiefer G, Lehmann H. Anticytoplasmic antibodies in Wegener's granulomatosis. Lancet 1986;i:806.

4 Ludemann G, Gross WL. Autoantibodies against cytoplasmic structures of neutrophil granulocytes in Wegener's granulomatosis. Clin Exp Immunol 1987; 69:350-7.

5 Rasmussen N, Wiik A, Hoier-Madsen M, Borregaard N, Van der Woude F. Antineutrophil cytoplasm antibodies. Lancet 1988;i:706-7.

6 Lockwood CM, Bakes D, Jones S, Whitaker KB, Moss DW, Savage COS. Association of alkaline phosphatase with an autoantigen recognised by circulating antineutrophil antibodies in systemic vasculitis. Lancet 1987;i:716-20.

7 Harrison DJ, Simpson R, Neary C, Wathen CG. Renal biopsy and antineutrophil antibodies and renal biopsy in the diagnosis and assessment of Wegener's granulomatosis. Br J Dis Chest 1988;82:398-404.

8 Lockwood CM. [Letter.] Lancet 1987;i:1489-90.

9 Wathen CG, Harrison DJ. Circulating antineutrophil antibodies in systemic vasculitis. Lancet 1987;i:1037.
10 Venning MC, Arfeen S, Bird AG. Antibodies to neutrophil cytoplasmic antigen in systemic vasculitis. Lancet 1987;ii:850.

11 Wathen CG, Harrison DJ, Bell D, Davies J, Douglas AC. Determination of disease activity of Wegener's granuloma. Scott Med J 1988;33:221.

12 McCluskey RT, Fienberg R. Vasculitis in primary vasculitides, granulomatoses, and connective tissue disease. Hum Pathol 1983;14:305-15.

13 Leavitt RY, Fauci AS. Pulmonary vasculitis. Am Rev Respir Dis 1986;134:149-66.

14 Savage COS, Jones S, Winearls CG, Marshall PD, Lockwood CM. Prospective study of radioimmunoassay for antibodies against neutrophil cytoplasm in the diagnosis of systemic vasculitis. Lancet 1987; 1389-93.

15 Harrison DJ, Kharbanda R. The characterisation of antibodies to neutrophil cytoplasmic antigens in systemic vasculitis. Nephrol Dial Transplant 1988;3:526.

16 Penning CA, Jones S, Lockwood CM. Antibody binding profiles of sera from systemic vasculitis patients. Nephrol Dial Transplant 1988;3:527.

17 Gross WL, Ludemann J, Schroder J-M. Antineutrophil cytoplasm antibodies in Wegener's granulomatosis are not directed against alkaline phosphatase. Lancet 1987;i:1488-9.

18 Sharpe GC. Mixed connective tissue disease-an apparently distinct rheumatic disease syndrome associated with a specific antibody to an extractable nuclear antigen (ENA). Am J Med 1972;52:148-59.

19 Williams ARW, Wyllie AH, Piris J. Immunohistochemical demonstration of p62 myc oncogene product in human colonic neoplasms [abstract]. J Pathol 1987;152:234A.

20 Rasmussen N, Borregaard N, Wiik A. Antineutrophil cytoplasm antibodies in Wegener's granulomatosis are not directed against alkaline phosphatase. Lancet 1987; i:1488.

21 Goldschmeding R, Tetteroo PAT, Von der Borne AEG, Kallenberg CGM. Antineutrophil cytoplasm antibodies in Wegener's granulomatosis are not directed against alkaline phosphatase. Lancet $1987 ; \mathrm{i}: 1489$. 